\title{
From the criminological legend to the criminological chimera
}

\begin{abstract}
The essayist presents His staff view on the past, present and future of criminology and criminal law, using metaphors of legend, myth and illusion, as a system of popular beliefs About Real phenomena That are Intended to conceal the true purpose for Which They are built and maintained, explaining and justifying the status quo through the history of peoples.
\end{abstract}

Keywords: legend, myth, chimera, crime, criminal law, criminology, criminological positivism, new criminology, critical criminology, economic and social structures, political economic theory of deviance

\author{
Volume 6 Issue 5 - 2018
}

\section{Gino Rios Patio}

Director of the Institute of Legal Research, University of San Martin de Porres, Lima, Peru

Correspondence: Gino Rios Patio, Lawyer and university
professor of Criminology, Director of the Institute of Lega
Research, University of San Martin de Porres, Lima, Peru,
Email griasp@usmp.pe

Received: June 18, 2018 | Published: November 16, 2018

\section{Liminal words}

In Greek culture of antiquity the usual story was a myth referred to portentous events, by striking, such as gods, demigods, titans, idols, giants, monsters or fantasy characters beings. Today it is considered in much of the world, a story. Myths are, in a culture or community, a system of dogmas that are considered authentic stories and together is called mythology, which bears a direct relationship with community beliefs: A greater number of myths and greater complexity of a mythology, the greater the development of the beliefs of a community that supports their worldview. As word and concept, the myth began to lose credit and devalue to acquire a derogatory meaning, coming to be used loosely as a synonym shaped canard of widespread but false belief at the time that philosophical disquisitions and scientific elucidations appeared and were knowledge of the community. It is known to position estructuralista Levi-Strauss anthropologist, ${ }^{1}$ whereby, myth consist irreconcilable antipodes, such as creation against destruction, life against death, or against bad; and it provides the reconciliation of these extremes to exorcise our consciousness. Also, Parker ${ }^{2}$ refers to the functionalist anthropologist Malinowski argued that each of the components and social institutions relate to each other within a system in which everyone has a role. As an example, he highlighted the characteristics of beliefs, customs, institutions, religions and rituals, among others. From the foregoing it is possible to deduce that there is no substantial aspect of life that is alien to the myth, because this answers the basic questions of human existence, that is, reason and reason to exist around him, among others. The downside is that is not a rational explanation. At the popular level, the myth plays an explanatory role because it explains, justifies or develop the cause of some aspect of social or individual life; a function of meaning, because it gives a comfort that relieves individuals; and a pragmatic role since it is the basis of certain structures and state actions. It is possible that these three combined functions are played simultaneously in the social policy area, as will occur to criminal law. While the myth, the story, the legend and the chimera have similar meanings, there are some differences between these concepts. The story, for example, is a flat aetiological fiction, while the myth is presented as a credible albeit complicated plot story. Moreover, the legend, unlike the myth, takes place in a real, historical time, in certain places and with real actors. In turn, the chimera of the imagination is seen as something possible to be unworkable. It is customary to read the myth literally, being an object of social belief, which meaning cannot be other than an imaginary and symbolic; however, the interpretation should be to identify in reality what is used in everyday life, as reinforcement of behaviours, argument of authority, among other things; analyze and define the reality opposites or complementary elements that appear in it and how they appear related; and reason his notorious symbolism, filled with an impact that refers to archetypical content of the human psyche. In this essay, I intend to examine the mythical character of criminal law, the beginnings of legend criminology and chimerical nature of radical criminology from the Peruvian reality, which keeps similarity with the criminological reality and Latin American criminal.

\section{Traditional criminological LEYENDA and mythology criminal}

It is known theory Cesare Lombroso in 1876 about the born criminal, according to which the offender is born and exhibits marked physical, such as small eyes, bushy eyebrows, forehead little crooked nose, thick lips, swollen eyelids, robust jaws features, stooping, among other features, depending on the type of crime. Such thinking was, however, accepted and because it had anesthetic effects on the parent and homemaker, because they felt reassured because no family member or neighbour had those traits and therefore could not be able to harm them. The same feeling then benefited the minister, businessman, industrial, military, medical, judge, attorney, among others. Thus, the criminological classicism represented by the positivist criminology, obtained its revenues in the emotionality of the population and the formal social control, because the state needed a paralegal useful rationalization to justify more selective and targeted on purpose repression. Then he began to build over time a criminological legend up with us today, although no longer in criminological theory, but continues in the criminal reality as a myth, according to which the offender still has mostly the characteristics horrible poor, grotesque, belonging to the tiniest social classes, mental health problems, uneducated and hereditary defects or genetic aberrations. As in the myth, the legend met an explanation, justification, meaningful and pragmatic function, because it sought to determine the natural causes 
of crime; giving relief to individuals that escaped the described physical characteristics; and be the basis of the structure and the penal system. Obviously, unlike the myth, the legend happening (and it happens) in a real, historical time, in certain places and with real actors. And it has always required myths to explain and represent the evil or obscurely risky; to focus, by contrast, the venerable strip of good and positively sure. Thus, the traditional criminological legend continued to feed this myth of Criminal Law. Furthermore, as a correlate of the previous, a second myth stood... consisting criminals are in prison as orates in manicomio, which involves two aspects of one institutionalized control device, characterized by repression, proscription and confinement, to theoretically claim a scientific recipe of the problem, healing them, reinserting, rehabilitating them, but fundamentally hiding repression and state violence, which came to be called criminological political power of social defence, which still persist in our Latin American reality, but of course, it is obvious that only for the most vulnerable and economically handiest social classes.

Our prison situation is precisely abominable this second penalty myth described above, due to the tendency of our criminal judges prefer the deprivation of liberty as a general rule and appear as an exception, exactly the opposite of what it should be, not to affect the dignity of the human being. The high rate of internal condition in custody, ${ }^{1}$ Certifies that the jurisdictional considerations about the danger of leakage and obstruction of the investigation of the truth, based on the broad discretion conferred on it by Articles 268 and 269 of the Criminal Procedure Code to criminal judges to justify a term of preventive detention not follow most of the time legally reasonable judgment. Moreover, the penal system in general and criminal law in particular are addressed not necessarily those of the majority or by a social consensus, which certainly sometimes product of manipulation exerted by the mass media of is given public opinion, but in society who have the power to apply its criteria, which constitute a veritable arsenal of such a group or class against those who circumstantially flying a different interest them. Then for the system and criminal law, the offender is presented as a morbid pathogen to be healed, restored, so that they form a consensus aimed at legitimizing his power, a situation that is a form of subtle subliminal violence, which we are facing a third penalty myth. To say Gramsci, ${ }^{3}$ that tenuous violence of the ruling class that constructs an artificial consensus becomes hegemony, resulting in the promotion of the ideology of that class. So Rodriguez and Dry ${ }^{3}$ argue correctly that Gramsci is a basic reference for thinking about building democratic possibilities in the XXI century in terms of an open understanding of the concept that transcends the formal concept and rejects its abstract display or metaphysics of political project finished, when we see that is under construction. It is this mythical vision of the system and the criminal law that invades us and obstinately defend a penal institution ineffective, evil, mind-blowing and false, unable to open up to new possibilities able to introduce the idea of respect for the singularities that make up the collective. Every day we draw from the mythical vision of democratic vision of the dominant ideology of a structure of government that does not govern delivery, because the criminal justice system does not stop the rate of violence and crime, hence the political myth of popular representation serve to support the criminal myth. Again, as Gramsci said, quoted by Rodriguez and $\mathrm{Seco}^{3}$ democracy is also reflecting from everyday

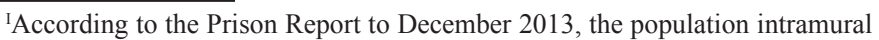
mandatad pre-trial detention is 36.670 people, while the population of sentenced inmates is 30, 927 people. Source: Units Prison Records. Preparation: INPE / Statistics Unit. Recovered from http://www.inpe.gob.pe/pdf/Diciembre2013. pdf practices, in our case, from the lacerating criminal practice. Gramsci's thought, according to Fernandez, ${ }^{4}$ it is then useful for analysis and critical assessment of our democracy in the face of formulating proposals therefore is effective and allows rediscover the group or the ruling class incorporates the middle class ((intellectuals, scientists) with no ability for the original project, making the administrators of the ideology of the ruling class deviates. This makes organic articulation between the superstructure (ideology) and economic structure. According to Castro the sense of its operation, the system and criminal legal system is the political class and the dominant group, as is coercively impose their values when the consensus is created with civil society is ineffective. Criminal dogmatic doctrine and fulfils the role of commitment. The mediating role of cultural bodies (school, church, media, science, civil society) is ratified by an analysis of values and beliefs of the subaltern classes. It is therefore manipulated consensus that exists on the criminal justice system. In that sense, the powers of definition of criminal conduct, labelling and assignment of suspicion and guilt and enforcement of criminal sanctions, belong to the ruling class, with no possibility of equality in the criminal justice system, because it has been rebuilt socially deliberately reality. Indeed, this situation results in a final criminal myth, which is presented as everyone has the same chance of being singled out as criminals be apprehended and punished, which is obviously false. Reality shows us not only through social processes that occur in the facts, but through legislation and the penal system on the one hand, that he who has money, contacts with common and powerful interests or power, not it is reported, processed or charged; and secondly, that he who violates prevalently interests that do not affect the system, has legal solutions to prevent, delay or halt criminal proceedings. According to this myth, our society is divided in accordance with the law and stereotypes, offenders and good citizens, in a Manichean and false conception of human behaviour. It is that productivity, consumption and individual enrichment, are always guaranteed codes, courts and police in the service of the powerful class. panoramically We wanted to show some longstanding myths criminal, arising contemporarily with traditional criminology that remain until today and, according to his fabulesca nature, seek to justify the criminal justice system; hypothetical prove their effectiveness; and develop a symbolic function of reassurance to citizens from crime.

\section{The new criminology}

In 1949, Edwin Sutherland, American sociologist, gave the first truncheon criminal mythology to the Association of American sociology, arguing his theory of White Collar Crime, not covered by the codes, committed by respectable offenders and high status in the exercise of their business, which led to crimes began to be studied encoded of the hegemonic class and unreported crimes or dark figure that distorts the criminal statistics. As one can imagine, this first caning to criminological legend of positivist criminology, plunged into confusion and doubt scholars of criminal phenomenon then, as the only benchmark they had, that is, the immutable criminal law, whose normative budget provided "all" illegal harmful behaviours, collapsed and brought overland criminal myth. Thereafter, it was no use arguing that criminals were homeless or come from troubled homes; lacked resources of all kinds; and they had certain psychosomatic and anthropometric characteristics. Moreover, remember to Aniyar ${ }^{5}$ that the same Sutherland, with unconcealed irony, asserted that insufficient leg length was a significant variable for defining the criminal type, because the thief long legs runs faster and it is not apprehended by law enforcement officials. Also, as regards Aniyar ${ }^{5}$ Giora Shoham said, 
more sharply, about the repetition of a variable in criminal detention, if in a city there are many stork nests on rooftops and coincidently more births, is reasonable to conclude that babies are brought by storks. That is, the criminal myth and legend criminological shamelessly exhibited face reality. Faced with such criminological nudity it was easy to see that the traditional stereotype of the offender (actually any stereotype offender) aimed to allow the ruling class to make their own crimes with impunity and derive the burden of aggressive criminal system to the lower classes as scapegoat, which otherwise would head towards that. So there is an ad hoc reality and social construction of crime, which makes some facts and not others, be considered criminal; and that certain criminals and not others expand the official crime statistics. Then came a new object of criminology, political partner and interests that promote the creation of criminal law mechanisms is what now makes her leave prison and go to investigate government offices, corporations, laws, courts, police, everything subjected to minorities. The Criminal Code can no longer reduce and contain criminology. In the most critical of the new Criminology end, the law is seen as a superstructure determined by the underlying social organization, divided into classes goes on to explain the social and political causes of crime, from the perspective of Radical Criminology.

The crux of capitalist ideology is to generate wealth for themselves at all costs, what follows that hypertrophy of the ego is criminogenic and hateful, which is further revealed when we think that grammatically the ego has no plural, since we it's me and you, that is, a genuine community. Therefore, the capitalist production system has a functional element that generates selfish and not altruistic values or community in crime. Therefore critical criminology demystifies understanding criminogenic causes of crime and functioning of the criminal justice system, denouncing the alienation produced by the capitalist system, breaking the unity of man with himself and nature, because it sells its workforce and product of his work for him does not have a utility in itself but a value as a commodity, which is tapped and hold those in power, which is enriched by plunder, which makes the capitalist system offender. Although Marx never wanted to criminology, his thought cannot be considered at this point as a materialist, but humanistic. Therefore, critical criminology helps to restore the dignity of man, yet the capitalist system considered a black sheep, that will issue only for its colour, the leaves grow and if it starts to give effect to its premises and try to change the actually, it proceeds to crush by the instruments of the system. Deviance in the National Conference, held in 1968 in England, Ian Taylor, Paul Walton and Jock Young, exponents of the new criminology, claimed that the deviation has indirectly from the economic and political situation, which is very dynamic. Routledge and Kegan, ${ }^{6}$ argue the effect that social psychology of crime may recognize that men can consciously choose the path of deviation as the only solution to the problems posed by the contradictory reality. On the other hand, Baratta ${ }^{7}$ argues that the nature and content of the crime cannot be captured without a complete analysis of its historical evolution, which involves the analysis a political economic theory of deviance, socially negative behaviours and criminalization on Marxist conceptual basis. It also criticizes the criminal justice system for production for criminal provisions (primary criminalization); the application thereof and criminal proceedings (secondary criminalization); and the execution of the sentence or security measure, which is the final stage of a selection process that begins before the intervention of the penal system with social and educational discrimination. From the foregoing, it follows that for radical criminology, crime is no longer an ontological quality of certain human and certain individuals behaviours, but a status assigned to certain people, through the selection of goods legally protected and offensive behaviour; and the choice of individuals stigmatized among all those who commit violations. Peruvian reality, at least, consistently shows this criminological view that criminal law is not equal for all and in the protection of property or the application of sanctions. $t$ is a fact that criminal law is a response to the symptoms and not the real causes, i.e., a mythology. So Ginbernat stated: "We are entering a time when the main task will be to lift the curtain of criminal law, to see what has really been hiding behind it". ${ }^{8}$ Hence, much actually is claimed that the new criminology offers opportunities for socially resolve fundamental issues, transcending the abstract structural theories or idealistic and neutralizing inequalities of wealth and power and property and life chances, otherwise it would be a correctionalism number.

\section{Chimera criminological}

According to Serrano 9 criminology has always been critical; for example, Lombroso only known for his theory of the born criminal, but in the fifth edition of his work Luomo delinquent, a third book about a real criminal sociology corruption of the powerful, oppression of the poor; justifies banditry as kind of wild justice against the oppressors; the influence of wealth on crime, the rich have more defence than the poor to justice; Shakespeare and making rags immediately denounce the crime among their holes, but gold hides and defends. In the same vein, Ferri ${ }^{10}$ states that criminal justice as an instrument of violent repression and class domination is destined to disappear not subsist except as clinical function. In "Dei delitti e delle pene" criticized the eighteenth century the old regime. As can be seen, the criminological positivism was denounced critical and political influence. It is that the criminologist, as a social scientist, must be examiner and censor, politically independent, for which no one should live in criminology, which in itself is a chimera. Reality shows us daily that those who most often violate the law are those who have the power, whatever the political system; therefore, no political party is interested in criminological research. Then the new criminology, contemporary criminology, critical or radical, postulates a possible conception to eliminate crime: the transformation of economic and political community, to make the most egalitarian, just and dignified coexistence social structures. Although necessary, this vindictive lawsuit happens not to be a legitimate aspiration, an ideal that calls for fighting the good and virtuous men; However, as the historical evolution of the people who have gone through this revolutionary path has been commissioned to demonstrate, it is impossible for the dichotomous, ambiguous and imperfect human nature itself; and as taught by the Cratología, the demonic nature of power, as biopsicoespiritual phenomenon that needs the state to maintain order and avoid chaos; It is axiomatic that scientific research should be directed to seek the truth, so, in that sense, a criminal investigation should not be based on what is given from criminal and who have violated criminal law legislation, but the legal system, the problematic nature of the legal system, so that criminology not have that ministerial character or helpful regarding criminal law. Enough of criminal guardianships that have prevented an autonomous vision of criminology, which, it is good to reiterate, don't belong to criminal science.

In Peru, for example, there is one Faculty of Criminology and a specialization at postgraduate level, the same is true in other Latin American countries. In Venezuela there is a Faculty. In Mexico there 
are eight public universities and more than 50 universities and colleges that offer this race; however, crime does not yield and periodically we sobrecogemos of moral pain with real news about massacres, such as that claimed the lives of 43 young students. Also, the vast majority of lawyers, and therefore judges are mere applicators (often arbitrary) laws, only a very small group exercises trying to form a new law. It is plain that every problem can find a solution in the analysis of social and individual causes, hence that criminal law is not the solution to the problem of crime in Peru and Latin America is serious because always late, when the crime has been committed and also suppresses only symbolic and selectively generating power from a delusion on citizenship. Furthermore, it is known that patterns of behaviour are not per se criminal, but as compared with other is that (pre) considered correct. And who (s) made (n) rules on patterns of social behaviour? Obviously, those who are serving those with political or economic power, so they are inclined to seek their own interest. It is undeniable that in every society there are social areas where it penetrates the law, labelling and stigmatizing offenders; and other impervious areas in which it does not, which is the golden figure of crime. Hence most of the true causes of crime necessarily have to do with the just satisfaction of the basic needs of the human person, equitable social distribution of wealth, equal opportunities before the law and to those who apply the law and social injustice, including socio-economic structural springs. Obviously, there are other individual causes for more than improve the socio-economic structure would not disappear deviant behaviour, however, they are quantitatively minority, so the prevention and control of crime itself has much to do with the structural causes socio economic, whose improvement would lead to a reduction in crime. Therefore, all that may be more effective to drastically prevent overflow of crimes, not their elimination, it could be the education of human beings in ethical values, which are stronger than the Penal Code and is, without a doubt the only tool capable of transforming the human being, the only suitable means to humanize him and rescue him from animalist in currently being debated in the midst of scientific and technological progress; and the only pertinent to remind its finitude, relativity and levity instrument, so that the earthly power can ever possess for a short time, use for the benefit of others and not to their detriment. Against which emerges legitimate hesitation about whether it is truly possible to overcome a matter of some stability, difficulty, as human as odious, inequality, selection and marginalization; however, it is necessary to reaffirm, on the one hand, the social structure that feeds these evils can and should be changed and, secondly, that the ethical and moral principles that must collect the law should not be questioned for the simple reason they are inspired by the demands of human sociability, whatever the social situation there. Therefore, consciously assume what claims the German professor Gustav Radbruch, that instead of doing a better criminal law, do something better than the criminal law.

\section{Conclusion}

a. The traditional positivist criminology is legend because it happened in a real, historical time and appeared and developed in some places and real protagonists; raising social beliefs of imaginary and symbolic meaning about crime and the criminal; It is used in everyday life for reinforcement of behaviours authority argument, among others, which had repercussions referred back to archetypal contents of the human psyche and feeding the various myths of criminal law. b. Criminal law has several myths develop a symbolic function of reassurance to citizens against crime, fabulescamente justifying the criminal justice system and pretending to prove their hypothetical effectiveness; when in fact the powers of definition of criminal conduct, labelling and assignment of suspicion and guilt and enforcement of criminal sanctions, belong to the political class and the dominant group, creating a manipulated on the penal system, hallucinating foster consensus but It does not guarantee that it is false, perverse, unequal and socially reconstructed reality deliberately.

c. The Penal Code can no longer reduce and contain criminology. Not outside the law is a superstructure determined by the underlying social organization, divided into classes goes on to explain the social and political causes of crime. Demystifies critical criminology understanding the causes of crime and criminogenic operation of the criminal justice system.

d. In everyday practice, the crime is more a status assigned to certain people, through the selection of goods legally protected, offensive behaviour and choice of individuals stigmatized among all those who commit violations; an ontological quality of certain human behaviours and certain individuals. In that sense, criminal law is a response to the symptoms and not the causes.

e. The transformation of socio economic and political community, to make the most egalitarian, just and dignified coexistence structures is an alternative response to control and reduce crime; however, this is nothing more than a legitimate aspiration, an ideal that calls for fighting the good and virtuous men, but in no way serves to weaken the expressions of imperfect human nature, let alone the irrepressible force of power defining policy, which act as sources of deviant behaviour.

f. It then requires man to evolve rather involution paradoxically through the advancement of science and technology, for which education in ethical values is stronger than the Penal Code, so it should be considered as the primary factor to curb the increase in socially deviant behaviour.

\section{Acknowledgements}

None

\section{Conflict of interest}

The author declares that there is no conflict of interest.

\section{References}

1. Levy-Strauss's work C. The structure of myths in Structural Anthropology I. Paidós: Barcelona. 1955.

2. Parker F. The McGraw Hill Encyclopedia of World Biography. The McGraw Hill Company Inc: New York. 1973.

3. Rodriguez R, Dry J. Hegemony and Democracy in the Twenty-first Century: Why Gramsci.

4. Fernandez F, Foreword. In Baratta G. Roses and note Brooks. Dialogic thinking of Antonio Gramsci, Barcelona, Bellaterra. 2003;13-14.

5. Aniyar L. Critical criminology or reality against myths. Criminal Law and Criminology. Journal of the Institute of Penal and Criminological Sciences of the Externado University of Colombia, Professional Editions Bookstore: Bogota, Colombia. 1979;2(8). 
6. Routledge, Kegan. The Political Economy of Crime. The new criminology. London Henley Boston. 1973.

7. Marcelo A. Critique of Criminology Review: A skeptical reading Baratta.

8. Gross M. Dogmatic new criminology and criminal justice. Notebooks criminal policy, Madrid 10.1980.
9. Serrano A. "Critical criminology" Yearbook of criminal law and criminal sciences. Publications of the National Institute of Legal Studies, Madrid. 1983.

10. Ferri E. Criminal sociology. Translation Hernández Soto, Madrid. 1907. 